\title{
Ekstraksi Zat Warna Dari Daun Jati Muda Dan Aplikasinya sebagai Kertas Indikator Asam-Basa
}

\section{Lisa Anggriani Putri, Agrippina Wiraningtyas, Magfirah Perkasa dan Ruslan}

\author{
Program studi Pendidikan Kimia STKIP Bima \\ Jl. Tendean No. 1 Mande Kota Bima \\ Email: lisaanggrianiputri@gmail.com
}

\begin{abstract}
ABSTRAK
Indikator merupakan zat yang dapat memberikan warna yang berbeda apabila direaksikan dengan larutan asam atau basa. Indikator sangat dibutuhkan dalam pembelajaran kimia, salah satu materi kimia yang membutuhkan penggunaan indikator adalah materi eksperimen asam-basa. Salah satu sumber bahan alami yang memliki potensi untuk dimanfaatkan sebagai bahan indikator asam basa adalah daun jati muda, dimana daun jati muda mengandung unsur tanin dan pigmen antosianin yang dapat dimanfaatkan sebgaai pewarna alami. Penelitian ini bertujuan untuk mengetahui pengaruh jenis pelarut terhadap warna ekstrak daun jati muda serta warna kertas indikator setelah diuji. Pelarut yang digunakan dalam penelitian ini adalah etanol 96\%, metanol 95\% dan air. Penelitian ini merupakan penelitian eksperimen kualitatif. Hasil penelitian menunjukkan bahwa jenis pelarut yang digunakan dalam proses ekstraksi mempengaruhi warna ekstrak dan warna kertas indikator, pelarut etanol 96\% dan metanol 95\% menghasilkan warna kertas lebih kontras dalam mebedakan larutan asam maupun basa yaitu warna coklat pada larutan asam dan hitam pada larutan basa.
\end{abstract}

Kata Kunci : Ekstraksi, Daun Jati Muda, Kertas Indikator Asam-Basa

\section{PENDAHULUAN}

Indikator merupakan zat yang dapat memberikan warna yang berbeda apabila direaksikan dengan larutan asam atau basa. Indikator sangat dibutuhkan dalam pembelajaran kimia, salah satu materi kimia yang membutuhkan penggunaan indikator adalah materi eksperimen asam-basa. Pada eksperimen asam-basa, indikator digunakan untuk menentukan sifat asam, basa atau netral suatu larutan. Oleh kerana itu, setiap sekolah seharusya menyediakan indikator, akan tetapai indikator yang sering dijumpai disekolah adalah indikator sintesis. Indikator sintesis memiliki kekurangan seperti memiliki harga yang mahal, sehingga pada kenyataannya masih banyak sekolah yang belum mampu menyediakan indikator sintesis. Selain memiliki harga yang mahal, beberapa diantaranya juga bersifat racun, dan tidak ramah lingkungan. Oleh kerena itu diperlukan adanya alternatif indikator asam basa dari bahan alami sebagai pengganti indikator asam basa sintesis.Salah satu sumber bahan alami yang memliki potensi untuk dimanfaatkan sebagai bahan indikator asam basa adalah daun jati muda.

Daun jati yang muda mempunyai ukuran yang lebar dan besar, dapat dijadikan sebagai perwarna alami karena selain menghasilkan warna coklat dari unsur tanin, daun jati juga mengandung pigmen antosianin. Warna merah dan ungu pada daun, bunga, batang dan umbi merupakan akibat dari adanya antosianin. Antosianin juga mempunyai sifat yang khas dan peka terhadap perubahan $\mathrm{pH}$. Pengambilan zat warna alami dari tumbuhtumbuhan dapat dilakukan dengan proses ekstraksi. Salah satu metode ekstraksi yang mudah, sederhana dan sering dilakukan adalah maserasi. Maserasi merupakan proses penyaringan simplisia dengan cara perendaman menggunakan pelarut pada temperatur kamar. Jenis pelarut yang digunakan dalam proses ekstraksi sangat mempengaruhi hasil 
ekstraksi. Pelarut air dan etanol merupakan pelarut yang sering digunakan dalam proses ekstraksi bahan-bahan alami disebabkan pelarut air bersifat polar dan etanol merupakan pelarut semi polar yang dapat mengekstrak zat warna dengan baik. Sedangkan pelarut metanol merupakan pelarut yang bersifat universal yang mampu mengikat semua komponen yang terdapat pada tumbuhan bahan alam, baik yang bersifat non polar, semi polar dan polar (Leny, 2006).

Berdasarkan uraian diatas, peneliti tertarik untuk melakukan penelitian tentang ekstraksi zat warna dari daun jati muda untuk digunakan sebagai bahan pembuatan kertas indikator asam basa dengan menvariasikan pelarut menggunakan pelarut air, etanol $96 \%$, dan metanol 95\%.

\section{METODE}

\section{Alat dan Bahan Penelitian}

Adapun alat dan bahan yang digunakan dalam penelitian ini adalah : Gelas Beker, corong, labu ukur, mangkuk kaca, gunting, pipet volum, spektrofotometer Uv-Vis, serbuk daun jati muda 45 gram, etanol $96 \%$, metanol 95\%, air, kertas saring, larutan $\mathrm{NaOH}$ dan HCldengan konsentrasi $1 \%, 16 \%$, dan $32 \%$.

\section{PROSEDUR PENELITIAN}

Prosedur penelitian dilakukan melalui beberapa tahap kegiatan sebagai berikut:

\section{Persiapan Sampel}

Daun jati muda yang digunakan dalam penelitian ini diambil di Kel. Nungga Kota Bima. Kemudian sampel dipotong kecil-kecil lalu di blender dan selanjutnya ditimbang sebanyak 15 gram.

Daun jati muda yang digunakan dalam penelitian ini diambil di Kel. Nungga Kota Bima. Kemudian sampel dipotong kecil-kecil lalu di blender dan selanjutnya ditimbang sebanyak 15 gram

\section{Tahap Ekstraksi Daun Jati Muda Menggunakan Metode Maserasi}

Sebanyak 15 gram daun jati muda dimasukkan kedalam tiga buah mangkuk dan ditambahkan pelarut etanol 96\%, metanol $95 \%$ dan air sebanyak $100 \mathrm{ml}$, kemudian direndam selama 5 jam. Ekstrak yang dihasilkan disaring menggunakan kertas saring. Tahap selanjutnya dilakukan uji kimia menggunakan spektrofotometer UV-Vis.

\section{Tahap Pembuatan dan Uji Kertas Indikator}

Kertas saringyang telah dipotong dengan ukuran $1 \times 4 \mathrm{~cm}$ dimasukkan kedalam labu yang berisi hasil ekstrak daun jati muda. Kertas saring dibiarkan selama 1 menit kemudian diangkat dan didinginkan menggunakan suhu ruangan.

Kertas saring yang telah direndam kedalam ekstrak daun jati muda tersebut dinamakan kertas indikator. Selanjutnya kertas indikator diuji dengan larutan $\mathrm{NaOH}$ dan $\mathrm{HCl}$ dengan konsentrasi $1 \%, 16 \%$, dan $32 \%$ sebanyak $5 \mathrm{ml}$. Kemudian diamati, dicatat dan difoto perubahan warna yang terjadi pada kertas indikator.

\section{HASIL DAN PEMBAHASAN \\ Hasil Penelitian}

Penelitian ini bertujuan untuk mengetahui apakah daun jati muda dapat digunakan sebagai indkator asam-basa 
Data Nilai Absorbansi Ekstrak Zat Warna Dari Daun Jati Muda Dengan Variasi Pelarut

Tabel 4.1 :Data Nilai Absorbansi Ekstrak Zat Warna Dari Daun Jati Muda dengan Variasi Jenis Pelarut.

\begin{tabular}{|l|l|l|l|}
\hline No & Jenis Pelarrut & $\begin{array}{l}\text { Panjang } \\
\text { Gelombang }(\lambda)\end{array}$ & Nilai Absorbansi \\
\hline 1 & Etanol $96 \%$ & 206 & 1.261 \\
\hline 2 & Metanol 95\% & 220 & 1.297 \\
\hline 3 & Air & 224 & 3.471 \\
\hline
\end{tabular}

Data Uji Fisik Warna Ekstrak Dan Kertas Indikator Dari Daun Jati Menggunakan Pelarut Etanol 96\%, Metanol 95\% Serta Pelarut Air.

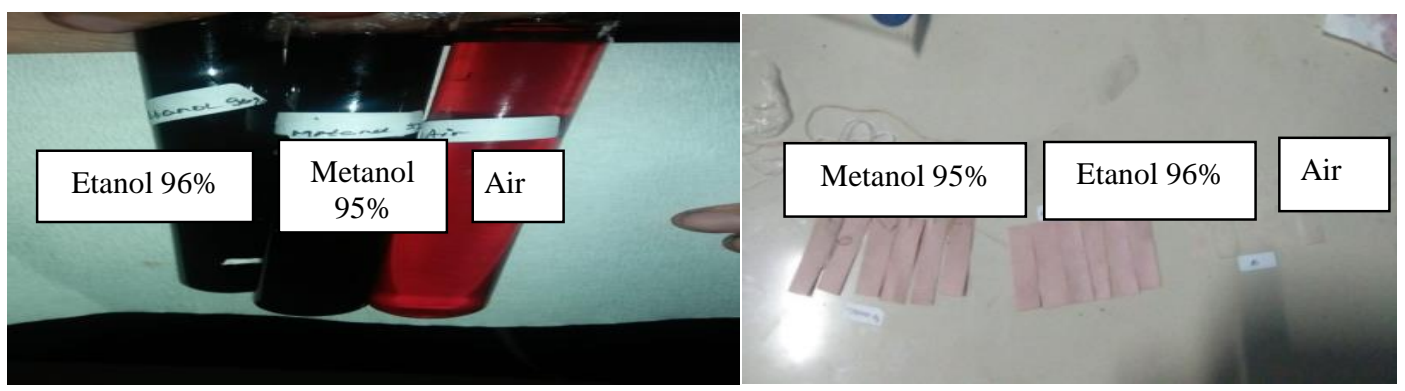

Gambar 1. (a) Warna Ekstrak Daun Jati Muda (b) Warna Kertas Indikator

Data Uji Fisik Warna Kertas Indikator Ketika Diuji Pada Larutan Asam-basa Dengan Berbagai Konsentrasi
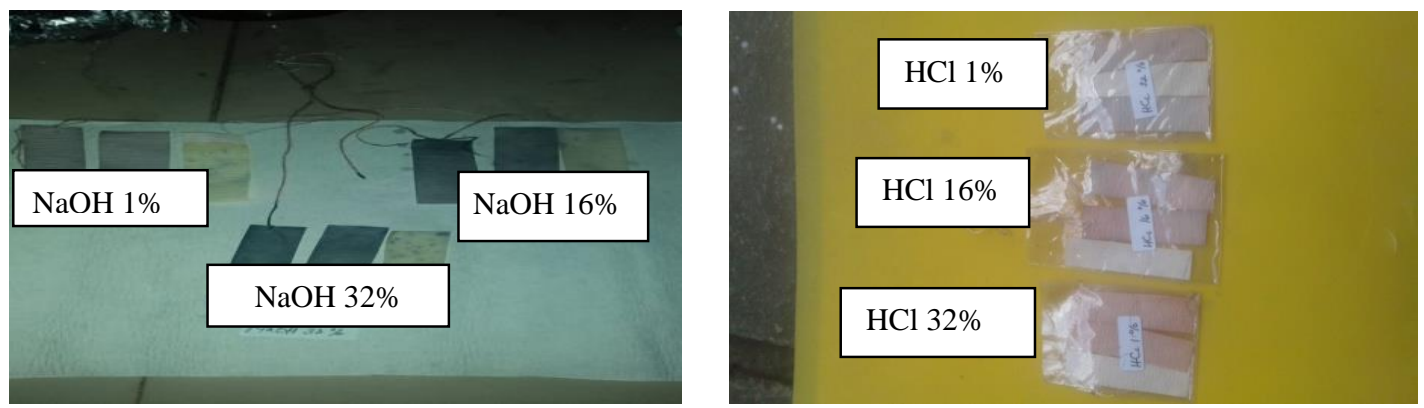

Gambar 2. Warna Kertas Indikator (a) Kertas Indikator Diuji Pada Larutan Basa (b) Kertas Indikator Diuji Pada Larutan Asam

\section{PEMBAHASAN}

\section{Ekstraksi Zat Warna Dari Daun Jati Muda}

Proses ekstraksi bertujuan untuk mengambil zat warna yang terkandung dalam daun jati muda. Dalam penelitian ini daun jati muda di ekstrak menggunakan berbagai variasi jenis pelarut. Daun jati muda yang telah diblender selanjutnya ditimbang sebanyak masingmasing 15 gram, kemudian dimasukkan kedalam 3 buah mangkuk kaca, dan ditambahkan pelarut etanol 96\% (mangkuk kaca 1), Metanol 95\% (Mangkuk kaca 2) dan air (Mangkuk kaca 3) sebanyak $100 \mathrm{ml}$. Daun jati muda direndam dimaserasi selama 5 jam, kemudian hasil yang diperoleh disaring menggunakan kertas saring.

Berdasarkan hasil uji fisik dengan cara melihat langsung warna yang dihasilkan menunjukkan bahwa daun jati yang diekstrak dengan pelarut etanol $96 \%$ menghasilkan 
warna coklat pekat, warna yang diperoleh sesuai dengan hasil penelitian yang dilakukan oleh (Wibowo. 2017) bahwa daun jati muda yang diekstrak dengan pelarut etanol 96\% menghasilkan warna coklat pekat. Warna ekstrak daun jati muda yang diekstrak menggunakan pelarut metanol $95 \%$ menghasilkan warna coklat pekat kehitaman. Warna coklat yang dihasilkan dalam ekstrak disebabkan karena daun jati muda juga mengandung unsur tanin. Unsur tanin dalam daun jati berfungsi untuk memberikan warna coklat (Marwati. 2010). Sedangkan daun jati muda yang diekstrak dengan pelarut air menghasilkan warna merah kecoklatan. Warna merah yang terbentuk dalam proses ekstraksi berasal dari pigmen sianidin, yang merupakan turunan dari antosianin (Afandy, dkk. 2017).

Ekstrak zat warna yang diperoleh diukur absorbansinya menggunakan spektrofotometer UV-Vis pada panjang gelombang 190-400 nm. Pemilihan panjang gelombang tersebut karena pada penelitian ini menggunakan spektrofotometer jenis daublebeam instrumen, dimana batas bawah (minimum) panjang gelombang adalah $190 \mathrm{~nm}$ sedangkan batas atas (maksimum) pada panjang gelombang $400 \mathrm{~nm}$. Menurut (Suhartati, 2017) pada panjang gelombang $400 \mathrm{~nm}$ merupakan batas maksimum senyawa organik dapat meneyrap sinar UV agar absorbansinya dapat terbaca.

Setelah diketahui panjang gelombang untuk pengukuran, ekstrak tersebut terlebih dahulu diencerkan sesuai jenis pelarut yang digunakan dalam proses ekstraksi. Pengenceran ini berfungsi supaya ekstrak yang diukur dapat terbaca nilai absorbansinya pada UV-Vis. Pada ekstrak daun jati muda yang menggunakan pelarut etanol 96\% dan metanol 95\% dilakukan pengenceran sebanyak 100 kali sedangkan untuk ekstrak daun jati yang menggunakan pelarut air dilakukan pengenceran hanya 10 kali. Hal ini dilakukan karena perbedaan tingkat kepekatan ekstrak yang dihasilkan dalam proses maserasi. Selanjutnya dilakukan uji kimia dengan cara melakukan pengukuran menggunakan spektrofotometer UvVis.Berdasarkan hasil uji kimia diketahui nilai absorbansi untuk daun jati muda yang diekstrak dengan pelarut etanol $96 \%$ yaitu sebesar $1,261(\lambda=206)$ dan ekstrak daun jati muda dengan pelarut metanol 95\% memiliki nilai absorbansi 1,297 $(\lambda=220)$. Sedangkan nilai absorbansi untuk ekstrak daun jati muda menggunakan pelarut air sebesar 3,471 $(\lambda=224)$.

Pada uji kimia nilai absorbansi tertinggi seharusnya diperoleh pada ekstrak yang menggunakan pelarut etanol 96\% dan metanol 95\%, karena warna ekstrak yang dihasilkan lebih pekat dibandingkan warna ekstrak menggunakan pelarut air. Hal ini disebabkan karena sebelum melakukan pengukuran pada spektrofotometer Uv-Vis, hasil ekstrak yang diperoleh menggunakan pelarut etanol $96 \%$ dan metanol $95 \%$ terlebih dahulu diencerkan dengan pengenceran 100 kali, sedangkan pada hasil ekstrak menggunakan pelarut air hanya dilakukan pengenceran sebanyak sepuluh kali, sehingga hal ini menyebabkan hasil ekstrak menggunakan pelarut air lebih pekat dibandingkan hasil ekstrak menggunakan pelarut etanol 96\% dan metanol 95\% dan mempengaruhi nilai absorbansinya. Absorbansi yang dihasilkan menggunakan pelarut etanol dan metanol memiliki perbedaan, hal ini disebabkan karena pelarut metanol memiliki struktur yang lebih sederhana dibandingkan etanol sehingga mampu mengekstrak lebih banyak komponen dalam sampel. Disamping itu, metanol memiliki tingkat kepolaran yang lebih tinggi dibandingkan etanol (Ruslan, 2019 dan Fadilah, 2019)

Dari data hasil uji fisik dan uji kimia dapat diketahui bahwa jenis pelarut yang digunakan dalam proses maserasi selain dapat mempengaruhi warna ekstrak daun jati muda, juga dapat mempengaruhi nilai absorbansinya. Semakin pekat hasil ekstrak yang dihasilkan dalam proses maserasi, maka semakin tinggi pula nilai absorbansinya, karena banyaknya jumlah molekul yang berinteraksi dengan sinar.

\section{Pemanfaatan Ekstrak Zat Warna Dari Daun Jati Muda Pada Kertas Indikator Asam-Basa}

\section{Pembuatan Kertan Indikator Asam-Basa}


Hasil ekstrak yang diporeleh dari proses maserasi digunakan untuk merendam kertas saring dengan ukuran $1 \times 4 \mathrm{~cm}$ sebanyak 6 lembar pada masing-masing jenis pelarut. Ukuran kertas saring diadopsi dari penelitian yang dilakukan (Sukemi, dkk. 2017). Kertas saring dipilih karena mengandung selulosa murni sehingga memiliki daya serap yang baik. Setelah kertas saring direndam selama satu menit, kemudian kertas saring tersebut dikeringkan.

Variasi jenis pelarut yang digunakan dalam proses maserasi dapat mempengaruhi warna kertas saring. Kertas saring yang direndam kedalam ekstrak daun jati menggunakan pelarut etanol $96 \%$ yaitu menghasilkan warna pich, dan warna pich lebih gelap pada pelarut metanol $95 \%$. Sedangkan pada ekstrak daun jati menggunakan pelarut air menghasilkan warna putih daisy. Hasil ini sesuai dengan hasil penelitian (Latih \& Rahayu. 2018), dimana kertas saring yang direndam kedalam ekstrak daun rhoeo discolor menggunakan pelarut etanol $95 \%$ dan etanol $95 \%+\mathrm{HCl} 1 \%$ menghasilkan warna yang berbeda pula, berwarna hijau pada ekstrak daun rhoeo discolor menggunakan pelarut etanol $95 \%$ dan merah muda pada ekstrak daun rhoeo discolor menggunakan pelarut etanol $95 \%+\mathrm{HCl} 1 \%$. Kertas saring yang direndam dalam ekstak daun jati muda ini dinamakan kertas indikator asam-basa.

\section{Pengujian Kertas Indikator Asam-Basa Pada Larutan $\mathrm{HCl}$ Dan $\mathrm{NaOH}$ Dengan Konsentrasi 1\%, 16\% dan 32\%}

Kertas indikator asam-basa yang telah dibuat selanjutnya diuji dengan larutan $\mathrm{HCl}$ (asam) dan larutan $\mathrm{NaOH}$ (basa) dengan konsentrasi $1 \%$, $16 \%$ serta $32 \%$. Variasi konsentrasi pada larutan asam-basa bertujuan untuk melihat perubahan warna kertas indikator pada setiap konsentrasi.

Berdasrkan gambar 4.6 diperoleh bahwa pada uji asam menggunakan larutan $\mathrm{HCl}$ (1\%, 16\% serta 32\%) kertas indikator yang dimaserasi dengan pelarut etanol $96 \%$ dan metanol 95\% menghasilkan warna coklat sandy brown, coklat sienna, dan coklat peru. Sedangkan kertas indikator yang dimaserasi dengan pelarut air menghasilkan warna putih ivory, putih linen, dan putih beige. Ketika diuji pada suasana basa menggunakan larutan $\mathrm{NaOH}(1 \%, 16 \%$ serta $32 \%)$ kertas indikator yang dimaserasi dengan pelarut etanol $96 \%$ dan metanol 95\% menghasilkan warna dark light slate gray, abu-abu, dark slate gray secara berturut-turut. Sedangkan kertas indikator yang dimaserasi dengan pelarut air menghasilkan warna kuning.

Dari hasil pengujian kertas indikator pada larutan asam dan basa menunjukkan bahwa terjadi penurunan intensitas warna kertas indikator seiring dengan bertambahnya konsentrasi laruatan $\mathrm{HCl}$ (asam). Sedangkan pada pengujian menggunakan larutan $\mathrm{NaOH}$ (basa) semakin tinggi konsentrasinya maka semakin tinggi pula intensitas warna kertas indikator yang dihasilkan. Hasil ini sesuai dengan penelitian yang dilakukan oleh (Sukemi, dkk. 2017) bahwa warna kertas indikator dari ekstrak etanol pucuk daun pucuk merah ketika diuji pada larutan asam mengalami penurunan intensitas warna seiring dengan kenaikan $\mathrm{pH}$, sedangkan pada pengujian basa mengalami kenaikan intensitas warna kertas indikator seiring dengan bertambahnya $\mathrm{pH}$. Kertas indikator asam-basa dari daun jati muda memiliki kelebihan dibandingkan kertas lakmus. Karena kertas indikator dari daun jati muda ini mampu memberikan perubahan warna disetiap kenaikan konsentrasi pada larutan asam atau basa. Sedangkan kertas lakmus hanya bisa menentukan sifat asam ataupun basa suatu larutan tanpa bisa menentukan nilai disetiap kenaikan $\mathrm{pH}$.

\section{KESIMPULAN}

Jenis pelarut yang digunakan dalam proses ekstraksi zat warna dari daun jati muda dapat mempengaruhi warna ekstrak yang dihasilkan. Daun jati yang direndam dengan pelarut etaol $96 \%$ menghasilkan warna coklat pekat, etanol 95\% menghasilkan warna coklat pekat kehitaman, sedangkan yang direndam dengan pelarut air menghasilkan wana merah kecoklatan. Jenis pelarut yang digunakan dalam proses ekstraksi zat warna dari daun jati 
muda dapat mempengaruhi warna kertas indikator asam-basa. Kertas saring yang direndam dengan ekstrak zat warna menggunakan pelarut etanol $96 \%$ berwarna pich, pich lebih gelap pada kertas saring yang direndam kedalam ekstrak yang menggunakan palarut metanol $95 \%$. Sedangakan kertas saring yang direndam dengan ekstrak zat warna menggunakan pelarut air berwarna putih daisy.

\section{DAFTAR PUSTAKA}

Afandy, A., Nuryanti, S., Wahid, A., 2017. Ekstraksi Ubi Jalar Ungu (ipomoea batatas L.) Menggunakan Variasi Pelarut Serta Pemanfaatannya Sebagai Indikator Asam-Basa"Jurnal Akademika Kimia Vol 6 () ISSN 2302-6030

Fadilah, R., \& Annafi, N. EKSTRAKSI ZAT WARNA DARI RUMPUT LAUT Sargassum sp MENGGUNAKAN PELARUT METHANOL. Jurnal Redoks: Jurnal Pendidikan Kimia dan IImu Kimia ISSN, 2614, 7300.

Leny, S. 2006. Senyawa Flavonoida, Fenil Propanoida, dan Alkaloida. Denpasar : Universitas Udayana Denpasar.

Lestari, P. 2016. Kertas Indikator Bunga Belimbing Wuluh (Averrhoa Blimbi L) Untuk Uji Larutan Asam Basa. Jurnal Pendidikan Madrasah Volume 1 (1).

Marwati, S. 2010. Kajian Penggunaan Ekstrak Kubis Ungu (Brassica oleracea L) sebagai Indikator Alami Titrasi Asam-Basa.Seminar Nasional Kimia MIPA UNY.Vol. (1) 547-553.

Suhartati, T. (2017). Dasar-Dasar Spektrofotometri UV-Vis dan Spektrometri Massauntuk Penentuan Struktur Senyawa Organik. Lampung: AnugrahUtama Raharja.

Sukemi, U, Putra, B.1, Purwati, W. 2017. Indikator Asam Basa Dari Ekstrak Etanol Pucuk Daun Pucuk Merah (Syzygium Oleana). Jurnal Kimia Dan Pendidikan Kimia. Vol.2 (3)

Wibowo, Vina. 2017. Pengaruh Ekstraksi Daun Jati Muda Dengan Variasi Jenis Pelarut Dan Lama Penyimpanan Terhadap Stabilitas Kertas Indikator Asam-Basa Alternatif. Surakarta : Universitas Muhammadiyah Surakarta

Wiraningtyas, A. (2019). EKSTRAKSI ZAT WARNA DARI RUMPUT LAUT Sargassum sp. Jurnal Redoks: Jurnal Pendidikan Kimia Dan IImu Kimia, 2(1), 1-10. 